\title{
Comprehensive Concept Model for Management Auditing in SMEs
}

\author{
Romana Kušnirová1,** \\ ${ }^{1}$ Institute of Technology and Business, Faculty of Corporate Strategy, Okruzni 517/10, 37001 Ceske Budejovice, Czech Republic
}

\begin{abstract}
The aim of this contribution is to present managers and owners of SMEs with a comprehensive concept for the preparation and implementation of a systemic approach to management auditing. The concept is presented in the form of a model called the "Systemic Approach to Management Audits", as developed by the author. The principle behind the model is to conduct individual audit activities according to a predetermined order, as represented by a sub-model called "Advised Activities during Management Audits". The model, or the application of a purposeful, standardized and, above all, systemic approach, was compiled on the basis of a two-phase questionnaire survey conducted in 2015/2016 and 2018/2019 among managers of SMEs, as well as guided interviews with professional auditors. The partial aim is to also highlight the relatively poor knowledge and implementation of management auditing in SMEs, and to encourage the use of the presented methodology by them.
\end{abstract}

Keywords: SME; management audit; management audit phase; audited areas; management auditing activities; systemic approach

\section{Introduction}

A management audit, in comparison with other audits (e.g. personnel, financial forensics, social, internal, innovation, etc.), evaluates and analyses an enterprise as a whole, specifically focusing on a detailed assessment of its internal environment. As a result, the implementation and processing thereof brings many advantages, as confirmed by several authors $[16,20]$. The most significant advantage is that it secures effective company management, followed by the establishment of the appropriate use and combination of resources, knowledge of the company's strengths and weaknesses, determination of the suitability of the organizational structure and corporate strategy, and the assessment of the style and principles of company management as such.

\subsection{Defining management audit}

A number of company managers, as well as some professional auditors, associate a management audit with a personnel audit, i.e. an audit of managers and their activities, characteristics and/or skills. However, this is a misconception because a management audit deals with the issue of analysing and evaluating effective company management. This is substantiated, for example, in the detailed definition of a management audit given by [9]. They state that a management audit is a comprehensive, systematic, independent and objective verification of the management environment, goals, strategies and activities of a company in order to identify problematic areas or actualities, to recommend and propose a plan of action that would improve the performance of the company's management.

\subsection{Implementation of management auditing}

Perhaps the best manner in which to consider the use and implementation of management auditing, and a systemic approach to it, is characterized by [11]. They define the approach as a logically arranged procedure of individual steps, phases, stages or activities that must be performed in a predetermined order because the individual steps (phases, activities) follow one another, as is also confirmed by [6]. Authors [4, 12] agree, recommending managers, as well as professional auditors, apply an implementation procedure that consists of 4 phases, i.e. planning (plan), organization (field work), data management (reporting), results (follow-up), as confirmed by [19].

The areas of focus of a management audit are suggested by [10], who perceives a management audit as an independent review of company management carried out by experts in the field of management and auditing, specializing only in this

\footnotetext{
${ }^{*}$ Corresponding author: pichova@mail.vstecb.cz
} 
particular type of review. The review covers all areas related to managing company operations, including production, control, marketing, management, sales, finance, personnel, etc.

\subsection{Goal and purpose of a management audit}

According to [3], the main goal and purpose of a management audit is to identify and evaluate the actual (current) state of a particular system/style/principle of company management used so far, which is reflected in finding and characterizing problematic area(s) in a company that prevents it from being managed effectively. According to [18], it may be argued that the goal of a management audit (based on resulting outputs obtained from its implementation) is to help managers and company owners to effectively manage companies and meet their set objectives (operational, tactical and strategic) and vision. Likewise, [3, 18] claim that on the basis of the evaluated information from a management audit, its goal and purpose is to assist managers and company owners achieve effective results while performing managerial functions, i.e. managing a company as a whole.

\section{Methodology}

The aim is to present company managers with significant evidence of the advantages of implementing management audits. The methodological model presented here includes suggestions on how to proceed with the implementation of management auditing, as well as which areas need to be analysed, whereby the focus is on small and medium-sized enterprises in the Czech Republic. Based on [13], the method of experimental modelling was selected to achieve the objective.

In relation to experimental modelling, a specific model called "Systemic Approach to Management Audits" was compiled as part of the comprehensive concept for the implementation of management auditing. The model consists of several sub-models in sequence (see Results and Discussion), and was designed on the back of the results of a two-phase questionnaire survey (involving managers of SMEs) and guided interviews with 12 professional auditors. The first phase was carried out in 2015/2016 and resulted in the creation of a key sub-model ("Management Model of Decision-Making"). The second phase, was conducted in 2018/2019, and in combination with the guided interviews with professionals (with a minimum of 10 years' experience), led to the development of a model concept for a systemic approach to management audits, including the areas that should be evaluated. The concept was generated only on the basis of the answers submitted by those respondents who prepare and implement such audits in their true sense, i.e. an assessment of the current state of the system of company management. The following table shows the results from both questionnaire surveys with regards to which participating SMEs (according to company size) perform or do not perform management audits or confuse the audit with other audits e.g. personnel, internal, etc.

Table 1. Questionnaire survey results - management audits by company size

\begin{tabular}{|c|c|c|c|c|}
\hline \multicolumn{5}{|c|}{ Questionnaire survey 2015/2016 } \\
\hline Company size & $\begin{array}{c}\text { Perform management } \\
\text { audits }\end{array}$ & $\begin{array}{c}\text { Do not perform } \\
\text { management audits }\end{array}$ & $\begin{array}{c}\text { Confuse management } \\
\text { audits }\end{array}$ & $\begin{array}{l}\text { Number of } \\
\text { respondents }\end{array}$ \\
\hline Micro- & 1 & 151 & 9 & 161 \\
\hline Small & 33 & 129 & 62 & 224 \\
\hline Medium-sized & 33 & 121 & 71 & 225 \\
\hline $\begin{array}{r}\text { Total number of } \\
\text { respondents }\end{array}$ & \multicolumn{4}{|c|}{610} \\
\hline \multicolumn{5}{|c|}{ Questionnaire survey 2018/2019 } \\
\hline Company size & $\begin{array}{c}\text { Perform management } \\
\text { audit }\end{array}$ & $\begin{array}{c}\text { Do not perform } \\
\text { management audit }\end{array}$ & $\begin{array}{c}\text { Confuse management } \\
\text { audit }\end{array}$ & $\begin{array}{l}\text { Number of } \\
\text { respondents }\end{array}$ \\
\hline Micro- & 5 & 28 & 8 & 41 \\
\hline Small & 17 & 45 & 16 & 78 \\
\hline Medium-sized & 33 & 71 & 32 & 136 \\
\hline $\begin{array}{r}\text { Total number of } \\
\text { respondents }\end{array}$ & \multicolumn{4}{|c|}{255} \\
\hline
\end{tabular}

Source: Author. 
The data in the above table shows that the participating SMEs do not perform management audits very often. Based on this finding, the following hypotheses were formulated:

- Hypothesis 1 (H1): The preparation and implementation of management audits is dependent on company size.

- Hypothesis 2 (H2): When preparing and implementing management audits, less than half of companies use a systemic approach.

- Hypothesis 3 (H3): When preparing and implementing management audits, more than half of companies evaluate more areas, not only the area of management.

H1 was evaluated on the basis of correlation analysis, as recommended by [8]. The following formula was used to assess the correlation analysis.

$$
r=\frac{\sum_{i=1}^{n}\left(x_{i}-\bar{x}\right)\left(y_{i}-\bar{y}\right)}{\sqrt{\sum_{i=1}^{n}\left(x_{i}-\bar{x}\right)^{2} \sum_{i=1}^{n}\left(y_{i}-\bar{y}\right)^{2}}}
$$

Figure 1. Pearson correlation coefficient

Source: Author

According to [7] and [8], H2 and H3 were evaluated on the basis of the application of a binomial test, for which the following formula was employed:

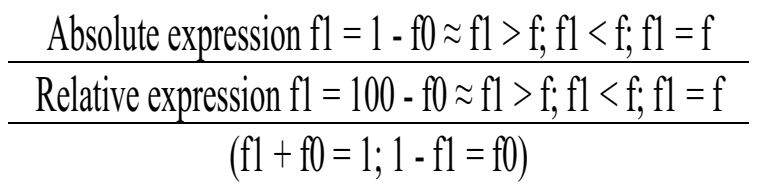

Figure 2. Principle of binomial test calculation

Source: Author.

\section{Results and Discussion}

\subsection{Principle of using systemic approach to management auditing}

The questionnaire survey revealed that SMEs process management audits sporadically. Of the 865 survey participants, only $122(14.1 \%)$ conduct management audits within the true sense of the meaning. Due to the relative unfamiliarity with management audits, previously created models that determine the main essence of a management audit are presented here. These indicate how to proceed with implementing a management audit and which areas to concentrate on.

In earlier publications, [5, 14 and 15], the author's own proposals on how to handle management audits as efficiently as possible were introduced in the form of a model, namely the "Management Model of Decision-Making" (see Figure 3). The model consists of three sub-models that complement one another, and which follows on from previously known and frequently used models (McKinsey 7S model, IFE matrix, VRIO Framework). The latter have been expanded and modified by the author for the purposes of management audit implementation.

The main goal of the first sub-model ("7S Adaptation Model") and the second sub-model ("Application IFE 7S Matrix") is to give an in-depth evaluation of the current company management system, whereby managers should concentrate on choosing an appropriate management style (i.e. effective company management as such). The third submodel ("Resource Model") evaluates company resources as a set of inputs, whose suitable allocation managers should focus on. 


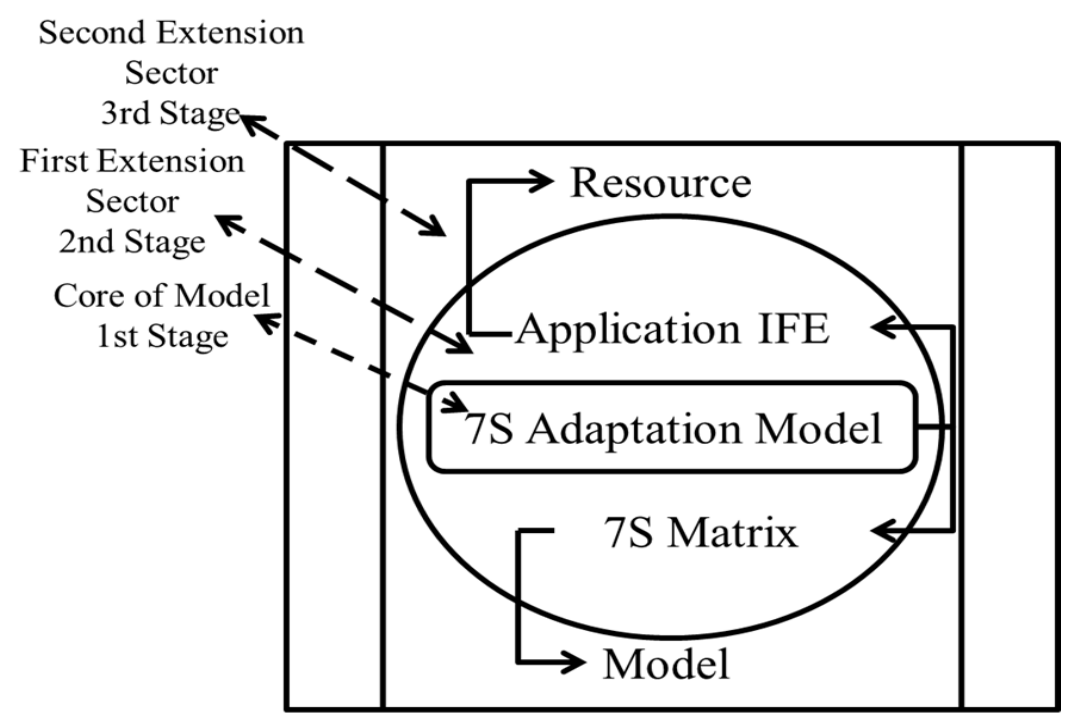

Figure 3. Stages of Management Model of Decision-Making

Source: Author.

In addition, in order to enable the implementation of management audits, the author generated a standardized procedure (see Figure 4) for the appropriate use of a systemic approach to them, as expressed by the model "Systemic Approach to Management Audits" (for more information see [15]). In order to fulfil the essence of management audits, i.e. to evaluate the current state of the system of company management, as well as the principle of a systemic approach to them, managers must be made aware of what needs to be analysed as part of a management audit. Given that purpose, the so-called "Managerial Questions" (see Table 2) were drawn up.

Table 2. Managerial Questions

\begin{tabular}{|c|c|}
\hline Examined Questions & $\begin{array}{c}\text { Factors patterned on the } \\
\text { 7S Model }\end{array}$ \\
\hline What does the company want to achieve and how does it want to achieve it? & Strategy \\
\hline What (composition of staff are required in the company? & Skills \\
\hline What abilities and skills does every employee need to have? & Structure \\
\hline What will be the hierarchical structure of the selected employees? & Style \\
\hline Which style of management should be used in the company? & Systems \\
\hline What systems should be used in the company? & Shalues \\
\hline
\end{tabular}

Source: Author.

Answering the above questions is the first step (and simultaneously the basis) of the entire "Systemic Approach to Management Audits" model (note 1), and is also part of the first stage of the "Management Model of Decision-Making". To make this even clearer, a specific list of questions (see Table 3) that makes up the structure of the "7S Adaptation Model" is given below. The evaluation of the questions can be performed separately by SMEs as part of their routine evaluation of the internal environment, whereby the recommendation to managers and owners of SMEs is to adhere to the original intention hereof and hence evaluate the questions both in terms of efficacy and efficiency.

Table 3. Evaluation questions

\begin{tabular}{|c|c|}
\hline Factors & Evaluation Questions \\
\hline Structure & $\begin{array}{c}\text { Is the organizational structure of the company flexible? Does the number of management } \\
\text { levels correspond to the specifics of the company? Are the superior-subordinate relationships } \\
\text { in the company clearly defined? Is (Are) the set degree(s) of centralization / decentralization } \\
\text { of powers to subordinates sufficient? Is the number of subordinates to individual managers } \\
\text { optimal, i.e. is the span of management in the company appropriately used? }\end{array}$ \\
\hline Systems & $\begin{array}{c}\text { Are suitable communication methods and techniques used in the company? Does the } \\
\text { company use an optimal combination of resources? Are appropriate and modern } \\
\text { management methods and techniques used in the company? Is the company able to correctly } \\
\text { respond to the changes in its corporate environment? Are appropriate information systems } \\
\text { used in the company? }\end{array}$ \\
\hline $\begin{array}{c}\text { Management } \\
\text { Style }\end{array}$ & $\begin{array}{c}\text { Do managers use an appropriate style of management with their subordinates in the } \\
\text { company? Do managers adapt the style of company management according to the current } \\
\text { situation in the company? Are the responsibilities of managers and their subordinates in the }\end{array}$ \\
\hline
\end{tabular}




\begin{tabular}{|c|c|c|}
\hline Staff & $\begin{array}{c}\text { company clearly defined? Do managers use the possibility of delegation of powers to their } \\
\text { subordinates, or is there abuse of their power over subordinates? Is teamwork used? }\end{array}$ \\
\hline $\begin{array}{c}\text { Does the company have an optimal (sufficient) number of employees? Are the employee } \\
\text { qualifications adequate for carrying out the job responsibilities? Do employees have any } \\
\text { opportunities for career growth and progression? Are the job descriptions of individual } \\
\text { employees, including their responsibilities, defined? Do managers use appropriate style(s) } \\
\text { and method(s) of motivation and evaluation of their subordinates? }\end{array}$ \\
\hline Skills & $\begin{array}{c}\text { Are managers at all hierarchical levels able to independently plan, organize, manage and } \\
\text { control? Are managers at all hierarchical levels able to compile plans so that these can } \\
\text { complement and follow one another? Are managers and their subordinates able to use a self- } \\
\text { management method? Do managers at all hierarchical levels use a management control } \\
\text { system and feedback control? Are the skills of managers and their subordinates sufficient for } \\
\text { the performance of their job? }\end{array}$ \\
\hline Strategy & $\begin{array}{c}\text { Has the company appropriately and clearly articulated its strategy? Is the company strategy } \\
\text { sufficiently and appropriately developed (divided) into short-term procedures and activities } \\
\text { (operations)? Has the company developed any concept of how to best meet the articulated } \\
\text { strategy and implement it? Has the company adequately formulated and established its } \\
\text { business goals and developed any concept of how to best achieve them? Are the goals, } \\
\text { visions and strategies realistic and feasible? }\end{array}$ \\
\hline $\begin{array}{c}\text { Shared } \\
\text { Values }\end{array}$ & $\begin{array}{c}\text { Are managers and their subordinates familiar enough with the company policy, goals, vision, } \\
\text { mission, tasks and strategy? Are managers and their subordinates sufficiently and informed } \\
\text { in good time about the company affairs and actions? Do managers and their subordinates act } \\
\text { in accordance with the established goals and values of the company? Are the competences of } \\
\text { all company employees clearly defined and are employees mutually aware of them? Has the } \\
\text { company formed its corporate culture that all employees are familiar with? }\end{array}$ \\
\hline
\end{tabular}

Source: Author.

Furthermore, the aforementioned systemic approach model was designed with respect to the principles of the PDCA cycle (as suggested by Deming), interviews with professional auditors (and their recommendations), observations made by [12], and was eventually arranged as four repeating elementary phases and related key management audit activities:

- P: Plan - planning of activities, i.e. planning management audit implementation, which also includes defining audit objective(s);

- D: Do - putting the plan into practice, i.e. management audit implementation, which is to evaluate the current company management system by responding to the "Managerial Questions" and processing the "Management Model of Decision-Making", see [15];

- $\mathrm{C}$ : Check - checking the result, i.e. comparing the current and desired state of the company management system and proposing measures (preferably 3 to 5) leading to the improvement of the system;

- A: Act - implementation of improvements, i.e. implementation of the proposed measures leading to a more effective company management system followed by re-evaluation of the current state of the system based on an assessment of the "Managerial Questions", as well as questions from the "Management Style" factor included in the "7S Adaptation Model". 


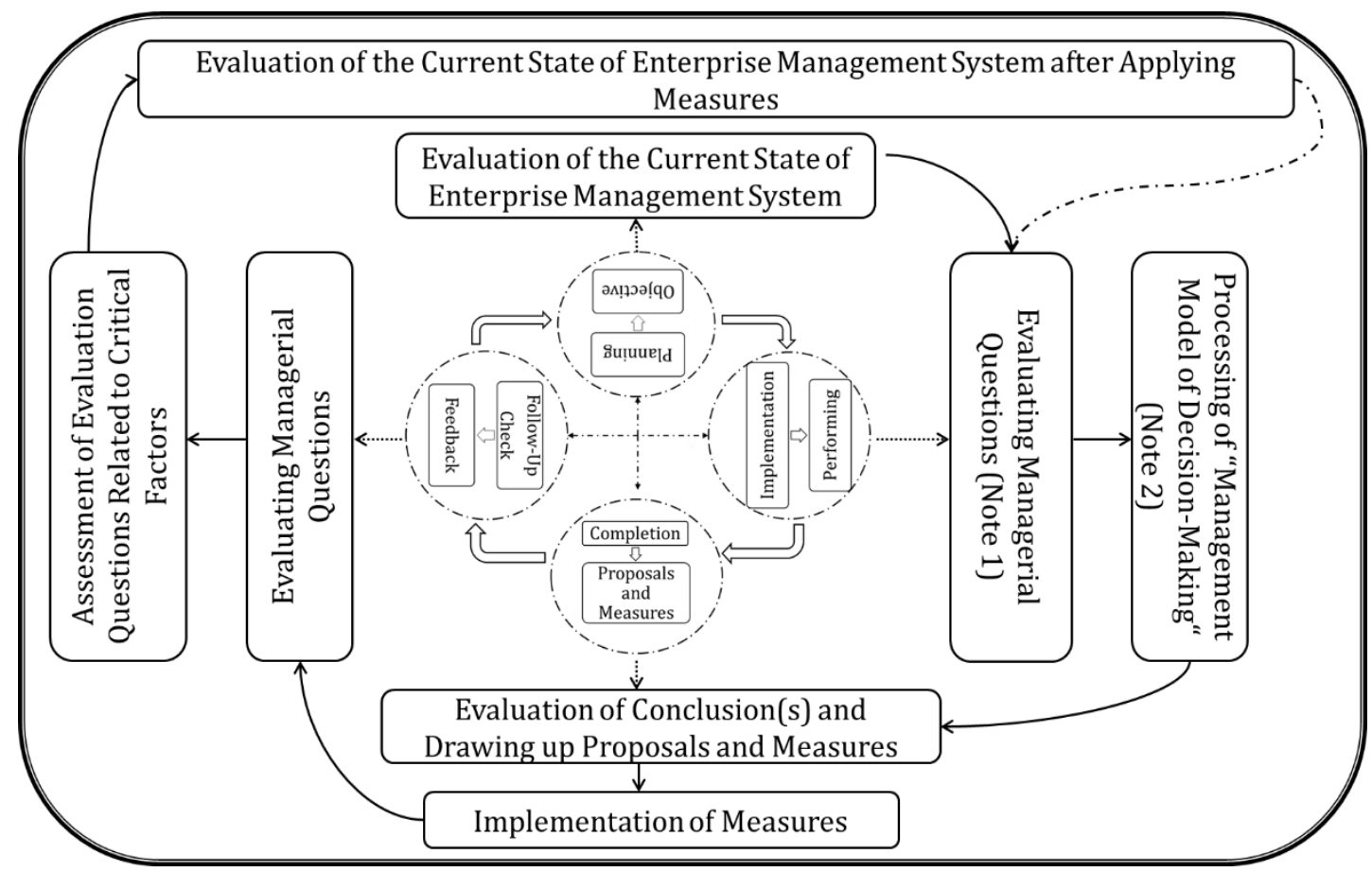

Figure 4. "Systemic Approach to Management Audits" model

Source: Author.

Furthermore, it may be added that the "Systemic Approach to Management Audits" model works on the assumption that a management audit is conducted in a specified order and time sequence, as presented in Figure 5 and previously in Figure 4, whereby the phases represent the basis for the model. As for the application of the model, the phases are characterized by specific activities that need to be carried out, as modified according to [17].

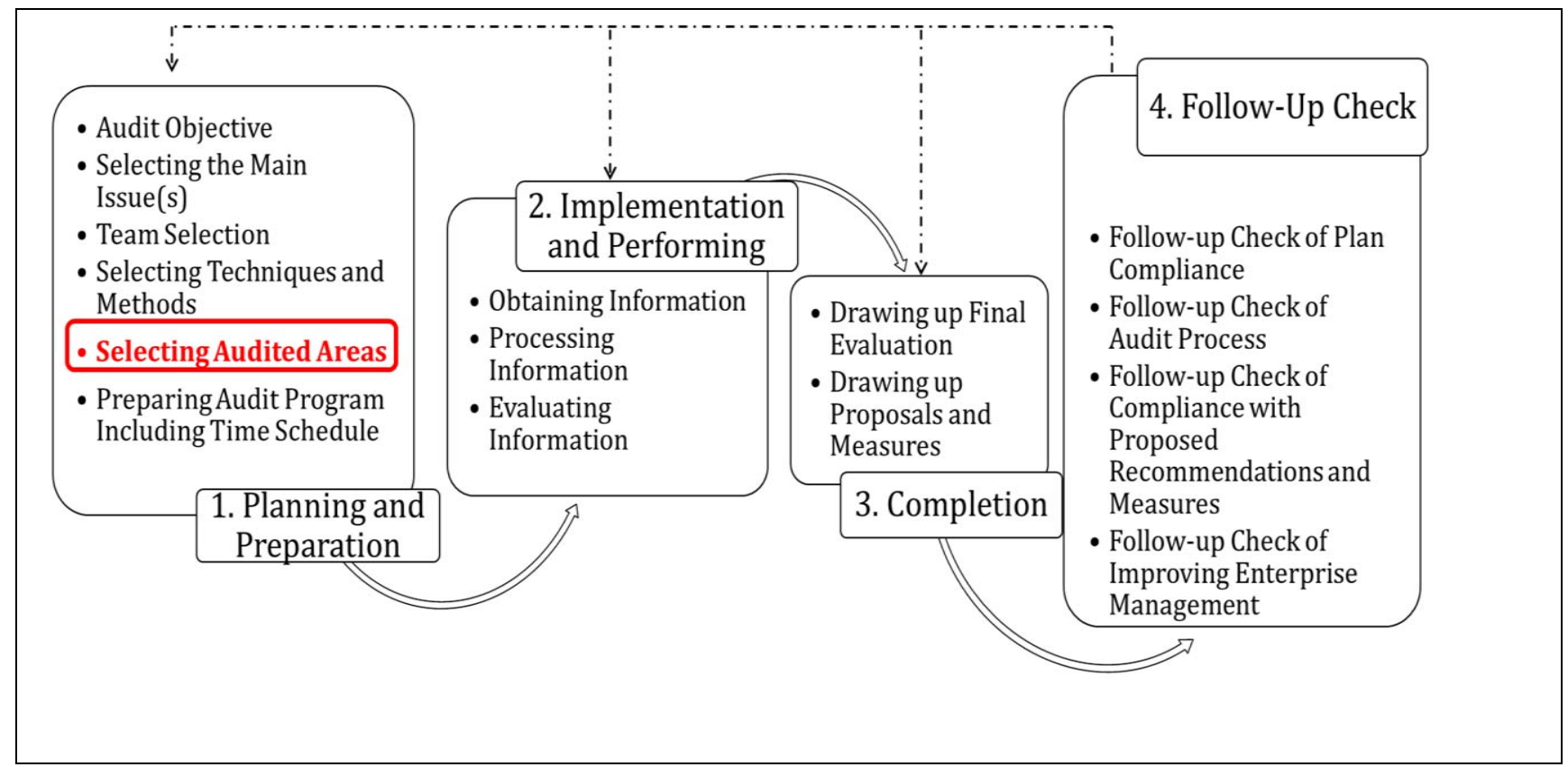

Figure 5. Advised activities during management audits

Source: Author.

The whole process must subsequently be extended with a "Six Area Auditing (6A Auditing)" model, as shown in Figure 6, which recognizes those areas that are suitable for auditing, as revealed by the survey. There are two prerequisites for the model. The first is that, in terms of management audits, companies tend to have multiple areas (not only the area of management) audited. The second is that the number of audited areas is affected by company size. The model therefore reflects both prerequisites and conforms with the requirements of managers of SMEs. 


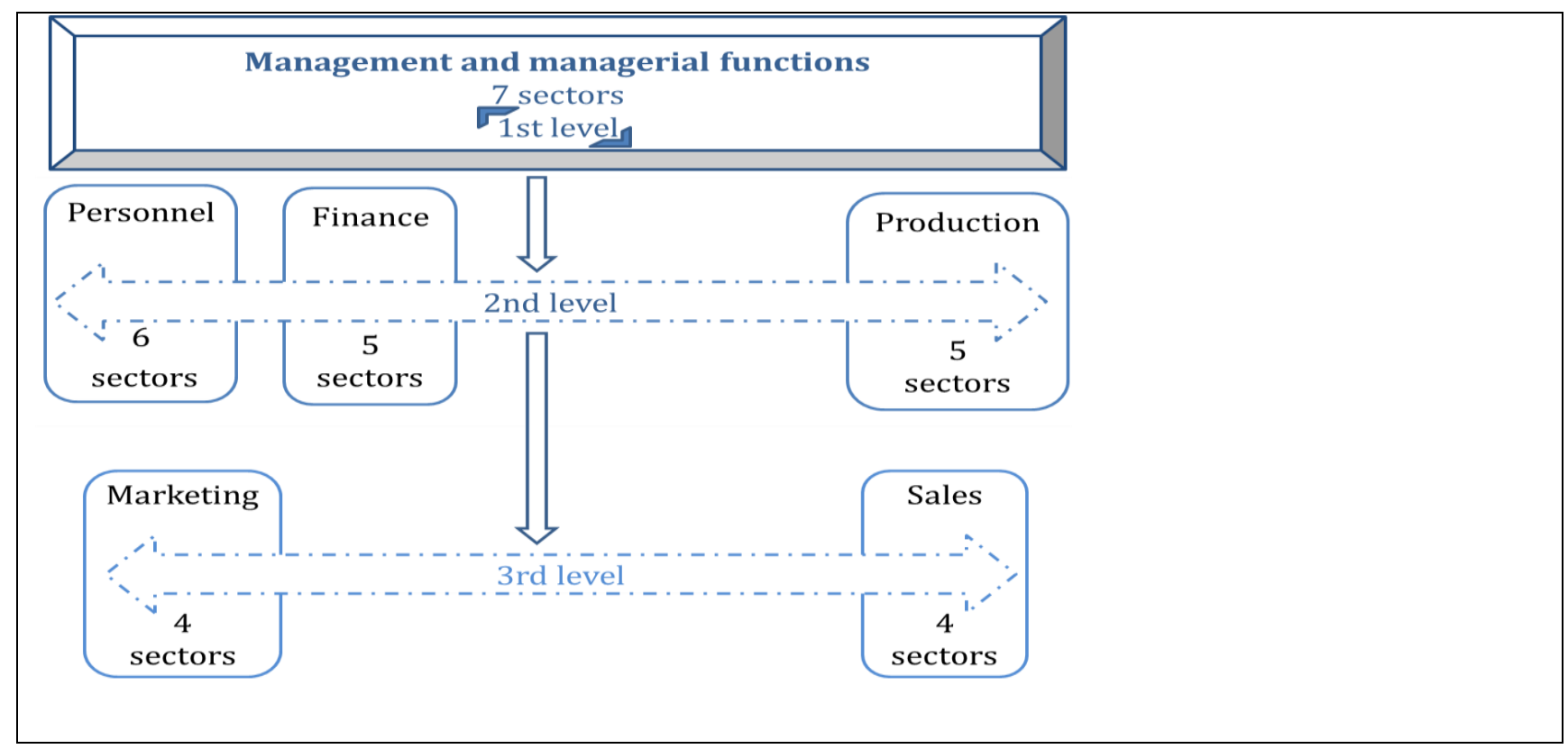

Figure 6. 6A auditing

Source: Author.

The above figure incorporates 3 levels, whereby the 1st level is essential and functions as a detailed assessment of the management area. On the basis of the "7S Adaptation Model", a total of 7 sectors have been allocated to "Management and Managerial Functions", which interconnects both models and puts them in sequence, in line with the stated aim of the author. The 2nd level (Personnel, Finance and Production) and the 3rd level (Marketing and Sales) should be viewed as added elements of a management audit, whereby certain consideration is only given to areas that habitually influence the management of a company. Besides the 1st level, small companies (11-50 employees) are advised to also audit areas of the 2nd level, whilst medium-sized companies (51-250 employees) are recommended to have a total of 6 areas audited, i.e. all 3 levels. In order to make the processing of the audit more feasible, numbers and names of sectors (see Table 4) have been allocated to each area in which their individual analysis is to be performed, since they mainly influence the given area as well as the management of a company as such.

Table 4. Areas and sectors of auditing

\begin{tabular}{|c|c|c|}
\hline Areas & Number of Sectors & Sectors \\
\hline $\begin{array}{c}\text { Management and managerial } \\
\text { functions }\end{array}$ & 7 & $\begin{array}{c}\text { Structure; Systems; Management Style; Staff, Skills; } \\
\text { Strategy; Shared values }\end{array}$ \\
\hline Personnel & 6 & $\begin{array}{c}\text { Work environment; Employee qualifications; Employee } \\
\text { performance ratings; Motivation and stimulation of } \\
\text { employees; Completed tasks; Workplace safety }\end{array}$ \\
\hline Finance & 5 & $\begin{array}{c}\text { Attitude to funding; Funding principle; Financial } \\
\text { reporting; Financial stability and profit; Investing } \\
\text { activities }\end{array}$ \\
\hline Production & 5 & $\begin{array}{c}\text { Production practices; Continuity of production process; } \\
\text { Production technologies; Products; Product range }\end{array}$ \\
\hline Marketing & 4 & $\begin{array}{c}\text { 4P (Product, Price, Place, Promotion); Direct marketing, } \\
\text { 4C (Customer solution, Cost, Convenience, } \\
\text { Communication); Customers }\end{array}$ \\
\hline Sales & 4 & Specification; Services; Logistics and expediting; Sales \\
\hline
\end{tabular}

Source: Author.

\subsection{Evaluation of hypotheses}

When evaluating the hypotheses, only those respondents from both surveys that conduct management audits in the true sense of the meaning were taken into consideration. The total number of respondents amounted to $\mathrm{n}=122$ (microcompanies $n=6$; small companies $n=50$; medium-sized companies $n=66$ ).

First, hypothesis $1(\mathrm{H} 1)$ was evaluated on the basis of correlation analysis and p-value. The correlation analysis involved determining the rules for assigning the evaluation coefficients presented in Table 5. The test set included only 
those companies in which it was determined that there was a competency to implement and process management audits in the true sense of the meaning.

Table 5. Principle for assigning evaluation coefficients

\begin{tabular}{|c|c|}
\hline Frequency & Evaluation coefficient \\
\hline Multiple times a year & 1.00 \\
\hline Once a year & 0.8 \\
\hline Once in 2 years & 0.6 \\
\hline Once in 3 years & 0.4 \\
\hline Longer time span or according to own needs & 0.2 \\
\hline
\end{tabular}

Source: Author.

The correlation analysis evaluation, including the p-value (i.e. confirmation/refutation of H1), is presented in Table 6 .

Table 6. Correlation analysis - H1 evaluation

\begin{tabular}{|c|c|}
\hline Variables & Resulting values \\
\hline Pearson correlation coefficient; $r$ interval $<-1 ; 1>$ & 0.1956179 \\
\hline $\mathrm{p}$-value $\alpha=5 \% ;(\mathrm{p}$-value $\leq 0,05)$ & 0.1523 \\
\hline
\end{tabular}

Source: Author.

The correlation analysis based on the Pearson coefficient calculation points to the fact that utilizing the competency to implement and process management audits does not depend on company size. The resulting coefficient value of $r=$ 0.1956179 indicates a direct but weak dependence between the variables. The direct, weak dependence is clearer in Figure 7.

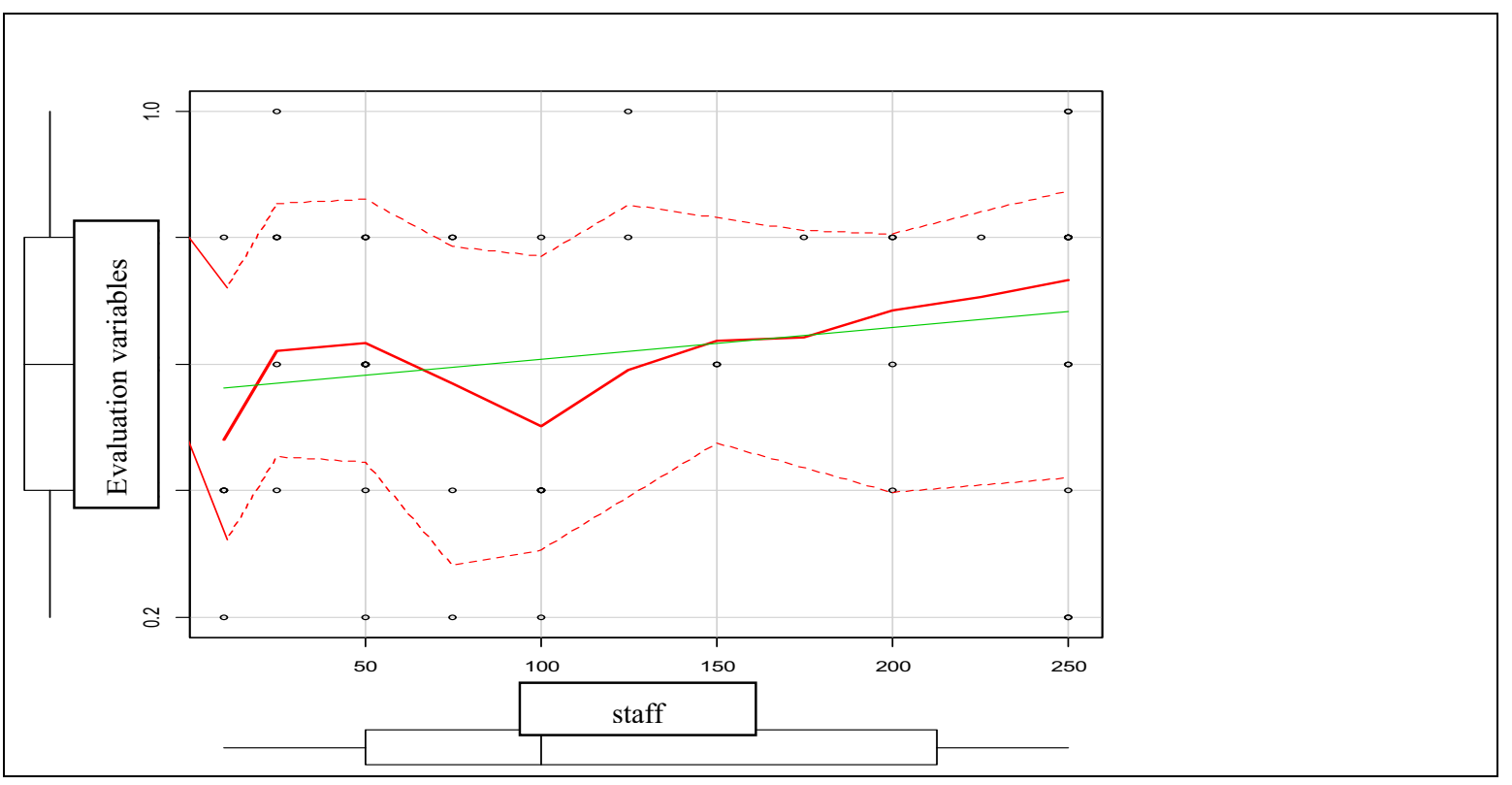

Figure 7. Graphical representation of correlation analysis

\section{Source: Author.}

The resulting p-value for hypothesis $\mathrm{H1}$ is higher than the specified level of significance of 0.05 , so it cannot be said that the correlation of the specified variables is significant. Therefore, hypothesis H1 (the preparation and implementation of management audits is dependent on company size) can be refuted.

The evaluation of hypothesis $\mathrm{H} 2$ was carried out in three stages. The first stage was to determine general criterion (1) and specific criteria (4). The general criterion involved conducting management audits in at least 4 phases, including the above audit content. The specific criteria were as follows: 1st Criterion - Phase 1: Audit Planning (Content: Defining audit objectives); 2nd Criterion - Phase 2: Audit Implementation (Content: Audit processing); 3rd Criterion - Phase 3. Audit Completion (Content: Drawing up proposals and measures to improve management); 4th Criterion - Phase 4: Follow-Up Check (Content: Feedback). The second stage involved assigning 0s and 1s (as the numerical values) in accordance with the categories specified in Table 7. The third stage involved a numerical assessment of the binomial test and the drawing of a conclusion. On the whole, the actual evaluation is the result of defining a desired frequency value (f), which was set at $\mathrm{f}=0.5$ as the absolute expression value, which corresponds to $\mathrm{f}=50 \%$ as the alternative for the relative expression value. If the resulting value ( $\mathrm{fl}$ ) is higher than $\mathrm{f}$ (see Figure 2), i.e. $\mathrm{fl}>\mathrm{f} 0.5(50 \%)$, the evaluation is negative, whereas if $\mathrm{fl}$ is less than or possibly equal to $\mathrm{f}$, i.e. $\mathrm{fl} \leq \mathrm{f} 0.5(50 \%)$, the evaluation is positive. 
Table 7. Principle of assigning categorical numerical values

\begin{tabular}{|c|c|c|}
\hline \multicolumn{3}{|c|}{ Category - audit implementation according to determined criteria } \\
\hline & Procedure according to determined criteria & Non-procedure according to determined criteria \\
\hline \multicolumn{3}{|c|}{ Categorical numerical values - Code assignment } \\
\hline Category & Non-procedure according to determined criteria & Procedure according to determined criteria \\
\hline Code & 0 & 1 \\
\hline
\end{tabular}

Source: Author.

The evaluation of the binomial test is presented in the following table (Table 8).

Table 8. Evaluation of binomial test

\begin{tabular}{|c|c|c|c|c|}
\hline Categorical numerical value & N & Evaluation & Frequency \\
\hline Non-procedure according to determined criteria & 0 & 88 & $1-\mathrm{f} 0<0.5$ & $\mathrm{f} 0=0.721$ \\
\cline { 5 - 5 } & & & $\mathrm{f} 1=0.279$ \\
\hline Procedure according to determined criteria & 1 & 34 & & $\mathrm{f} \sum=1.00$ \\
\hline
\end{tabular}

Source: Author.

On the basis of the calculated binomial test value, hypothesis $\mathrm{H} 2$ can be answered positively - YES (When preparing and implementing management audits, less than half of companies use a systemic approach), since the frequency value $\mathrm{f} 1=\mathbf{0 . 2 7 9}$ is lower than $\mathrm{f}=\mathbf{0 . 5}$.

Hypothesis H3 was also evaluated in three stages. The first stage involved establishing specific categories for assigning categorical numerical values. The second stage, once again, involved assigning 0s and 1s (as the numerical values) in accordance with the categories specified in Table 9. The third stage involved a numerical assessment of the binomial test and the drawing of a conclusion. On the whole, the actual evaluation is the result of defining a desired frequency value (f), which was set at $f=0.5$ as the absolute expression value, which corresponds to $f=50 \%$ as the alternative for the relative expression value. If the resulting value (f1) is higher than $\mathrm{f}$ (see Figure 2), i.e. $\mathrm{fl}>\mathrm{f} 0.5$ (50\%), the evaluation is negative, whereas if $\mathrm{fl}$ is less than or possibly equal to $\mathrm{f}$, i.e. $\mathrm{fl} \leq \mathrm{f} 0.5(50 \%)$, the evaluation is positive.

Table 9. Principle for assigning categorical numerical values

\begin{tabular}{|c|c|c|}
\hline \multicolumn{3}{|c|}{ Category - Analysis of areas } \\
\hline & alysis only of the area of management & Analysis of multiple areas \\
\hline \multicolumn{3}{|c|}{ Categorical numerical values - Code assignment } \\
\hline Category & Analysis only of the area of management & Analysis of multiple areas \\
\hline Code & 0 & 1 \\
\hline
\end{tabular}

Source: Author.

The evaluation of the binomial test is presented in the following table (Table 10).

Table 10. Evaluation of binomial test

\begin{tabular}{|c|c|c|c|c|}
\hline Categorical numerical value & N & Evaluation & Frequency \\
\hline Analysis of the area of management & 0 & 25 & \multirow{2}{*}{$1-\mathrm{f} 0<0.5$} & $\mathrm{f} 0=0.205$ \\
\cline { 2 - 3 } Analysis of multiple areas & 1 & 97 & & $\mathrm{f} 1=0.795$ \\
\hline Total & 122 & \multirow{2}{*}{$1-0.795=0.205$} & $\mathrm{f} \sum=1.00$ \\
\hline
\end{tabular}

Source: Author.

On the basis of the calculated binomial test value, hypothesis H3 can be answered positively - YES (When preparing and implementing management audits, more than half of companies evaluate more areas, not only the area of management), since the frequency value $\mathrm{fl}=0.795$ is higher than $\mathrm{f}=0.5$.

\section{Conclusion}

A clear conclusion may be drawn from the two-phase survey conducted. Although the managers or owners of the SMEs concerned are aware of management audits, they perform them very rarely in their true sense, i.e. an assessment of the current state of the system of company management. This finding was evaluated on the basis of processing obtained survey data, where $198(23 \%)$ of the total number of respondents $(n=865)$ confuse management audits with personnel audits, and 545 respondents $(63 \%)$ do not perform management audits at all. 
The results of the evaluations of the hypotheses shows that the preparation and implementation of management audits does not depend on company size (hypothesis H1 was therefore rejected), although it is clear that management audits are more often processed by medium-sized companies. Based on the confirmation of hypothesis $\mathrm{H} 2$, it can be claimed that the SMEs do not use a systemic approach to implementing management audits, which indicates that they do not have fixed rules on how to proceed with the implementation thereof. Out of the total number of respondents conducting management audits $(n=122)$, only 34 respondents $(28 \%)$ use such an approach. Based on the confirmation of hypothesis $\mathrm{H} 3$, through which the author wanted to determine whether the SMEs evaluate more areas than just management and managerial functions, it was discovered that 97 out of $122(80 \%)$ apply the procedure.

In light of the evaluations of hypotheses $\mathrm{H} 1$ and $\mathrm{H} 2$, it can be argued that the SMEs are missing out on an opportunity to streamline the principles and systems for company management. It is for this reason that the comprehensive "Systemic Approach to Management Audits" model, as outlined in this contribution, was proposed in order to encourage a systemic approach to the implementation of management audits. Based on the evaluation of hypothesis H3, the model was supplemented with specific areas, for which advice had been given to evaluate and analyse them as part of such an audit, thereby taking into account company size.

Finally, it is recommended that the managers and owners of SMEs pay closer attention to the implementation and processing of management audits, since the output thereof is an intention/prediction of how to manage a given company as effectively as possible in the future. On top of that, any company wanting to succeed against their competitors must first focus on their internal stability and constantly analyse their internal environment in order to achieve one of their main business goals, which is the continuous improvement of the system of company management. The author also agrees with opinions of $[1,2,16]$.

\section{References}

1. E. S. S. Alzoubi, Audit committee, internal audit function and earnings management: evidence from Jordan. Meditari Accountancy Research. 27(1), 72-90 (2019)

2. J. Belás, P. Bartoš, A. Ključnikov, L. Kozubíková, Významné determinanty kvality podnikatel'ského prostredia malých a stredných firem [Significant determinants of the quality of the business environment of small and mediumsized companies]. Scientific Papers of the University of Pardubice, Series D. 35, 5-17 (2015)

3. Ch. D. Bose, Principles of management and administration. $2^{\text {nd }}$ ed. New Delhi: PHI Learning Pvt. (2012)

4. L. D. Crumbley, U.S. Master Auditing Guide. $3^{\text {rd }}$ ed. Chicago: CCH INCORPORATED (2004)

5. P. Gallo, R. Píchová, A. Senkova, D. Matusikova, J. Mitrikova, Techniques and analysis of management audits. $C b u$ international conference proceedings 2017: innovations in science and education. 5, 132-137 (2017)

6. N. A. Hassan, S. H. Mohamad Zailani, H. A. Hasan, Integrated internal audit in management system: A comparative study of manufacturing firms in Malaysia. TQM Journal. 32(1), 110-126 (2019)

7. J. Hendl, Kvalitativní výzkum: základni teorie, metody a aplikace [Qualitative research: basic theories, methods and applications]. $4^{\text {th }}$ ed. Praha: Portál (2016)

8. R. Hindls, Statistika pro ekonomy. $8^{\text {th }}$ ed. Praha: Professional Publishing (2007)

9. P. T. Kotler, K. L. Keller, Marketing Management. 15 $5^{\text {th }}$ ed. Boston: Pearson (2016)

10. J. Law, A dictionary of business and management. $5^{\text {th }}$ ed. Oxford: Oxford University Press (2009)

11. P. Leung, P. Coram, B. Cooper, P. Richardson, Modern Auditing \& Assurance Services. $6^{\text {th }}$ ed. Hoboken: John Wiley (2015)

12. R. R. Moeller, Brink's modern internal auditing: a common body of knowledge. $8^{\text {th }}$ ed. Hoboken: John Wiley (2016)

13. Z. Molnár, S. Mildeova, H. Řezanková, R. Brixi, Pokročilé metody vědecké práce. Praha: Profes Consulting (2012)

14. R. Píchová, D. Raušer, Management Audit as a Tool for Managing Small and Medium-Sized Enterprises. In 7th International Scientific Conference on Managerial Trends in the Development of Enterprises in Globalization Era (ICoM) [online]. Available at: https://spu.fem.uniag.sk/fem/ICoM_2017/files/international_scientific_conference_icom_2017 (2017)

15. R. Píchová, D. Raušer, Principle of using systemic approach to management audit implementation by small and medium - sized enterprises. Scientific Papers of the University of Pardubice, Series D. 26(3), 209-220 (2018)

16. P. Psar, V. Kupec, Innovative controlling and audit-opportunities for SMEs. Problems and Perspectives in Management. 17(3), 184-195 (2019) 
17. R. Stefko, R. Pichova, P. Gallo, D. Rauser, A Systemic Approach to Implementation of Management Audit. In: 6th International Scientific Conference on International Business and Management, Domestic Particularities and Emerging Markets in the Light of Research [online]. Available at: https://www.unipo.sk/public/media/3948/ZBORNIK\%202016 (2016)

18. T. L. Wheelen, D. J. Hunger, Strategic management and business policy: concepts and cases. $13^{\text {th }}$ ed. Upper Saddle River: Prentice Hall (2012)

19. A. V. Zepeda, A. V. Ochoa, New public management based on rankings: from planning to evaluation. OPERACOLOMBIA. 21, 79-94 (2017)

20. Y. Zhaokai, K. C. Moffitt, Contract analytics in auditing. Accounting Horizons. 33(3), 111-126 (2019) 